\title{
PELATIHAN KETERAMPILAN BERBICARA BAHASA INDONESIA BAGI MAHASISWA DARI THAILAND DI UNIVERSITAS MUHAMMADIYAH PALANGKARAYA
}

\section{(Indonesian Language Course for Speaking Skill for Thai Students in Muhammadiyah University of Palangkaraya)}

\author{
Dwi Sari Usop"1), Lastaria ${ }^{2)}$ dan Arif Supriyadi ${ }^{1)}$ \\ ${ }^{1)}$ Program Studi Pendidikan Guru Sekolah Dasar (PGSD) Fakultas Keguruan dan IImu Pendidikan \\ ${ }^{2)}$ Program Studi Pendidikan Guru Madrasah Ibtidaiyah (PGMI) Fakultas Agama Islam \\ Universitas Muhammadiyah Palangkaraya \\ JI. RTA Milono Km.1,5 Palangka Raya, Kalimantan Tengah 73111 \\ e-mail : sari_1stlove@yahoo.com \\ llastaria@yahoo.co.id \\ Supriyadi.arif58@yahoo.co.id
}

\begin{abstract}
Indonesian speaking skills is essential for foreign students from Thailand who was educated in Indonesia, especially at Muhammadiyah University of Palangkaraya. Through skills for speaking Indonesian properly, Thai students were able to communicate with people residing in the vicinity. Particularly, in understanding the course material and expression.

Indonesian language course for speaking skill for Thai students in Muhammadiyah University of Palangkaraya aims to make the students able to recognize and understand the diversity of Indonesian and serves as a science to improve impaired speech in the Indonesian language, which will also affect the ability to write Indonesian.

Through course, Muhammadiyah University of Palangkaraya students' who came from Thailand has been quite able to recite the alphabet and make a simple sentence that can be used in communications. However, this ability stills needs to be aharpened in order to become proficient communicate using Indonesian.
\end{abstract}

Keywords: speaking skills, Indonesian language

\begin{abstract}
Abstrak
Keterampilan berbicara bahasa Indonesia merupakan bagian terpenting bagi mahasiswa dari Thailand yang menempuh pendidikan di Indonesia, khususnya di Universitas Muhammadiyah Palangkaraya. Melalui keterampilan berbicara bahasa Indonesia dengan benar, mahasiswa dari Thailand ini mampu berkomunikasi dengan masyarakat yang berada di sekitarnya. Khususnya, di dalam memahami materi kuliah dan menyampaikan pendapat.

Pelatihan keterampilan berbicara bahasa Indonesia bagi mahasiswa Universitas Muhammadiyah Palangkaraya dari Thailand bertujuan agar mahasiswa tersebut mampu mengenali dan memahami keanekaragaman bahasa Indonesia yang dapat berfungsi sebagai pengetahuan untuk meningkatkan kemampuan berbicara menggunakan bahasa Indonesia yang juga akan berpengaruh terhadap kemampuan menulis bahasa Indonesia.

Melalui pelatihan, mahasiswa Universitas Muhammadiyah Palangkaraya dari Thailand sudah mampu melafalkan alfabet serta mampu membuat kalimat sederhana yang dapat digunakan di dalam berkomunikasi. Walaupun demikian, kemampuan ini masih perlu diasah agar menjadi mahir berkomunikasi dengan bahasa Indonesia.
\end{abstract}

Kata kunci: keterampilan berbicara, bahasa Indonesia 


\section{PENDAHULUAN}

\section{Analisis Situasi}

Selama menempuh pendidikan di Indonesia, khususnya Universitas Muhammadiyah Palangkaraya, para mahasiswa ini dianggap cukup mampu menyesuaikan diri walaupun dengan usaha yang cukup keras. Namun, tidak menutup kemungkinan bahwa banyak kendala yang dihadapi oleh mahasiswa-mahasiswi dari Thailand selama menempuh pendidikan di Indonesia. Namun, tidak menutup kemungkinan banyak kendala yang dihadapi oleh mahasiswamahasiswi dari Thailand selama menempuh pendidikan di Indonesia. Khususnya, kendala di dalam mennyesuaikan diri. Hal ini dikarenakan keterbatasan mahasiswa-mahasiswi dari Thailand ini menggunakan bahasa Indonesia secara aktif. Dilihat dari kemampuan berbicara mahasiswamahasiswi dari Thailand ini cenderung menggunakan bahasa melayu sebagai bahasa yang digunakan sehari-hari. Sebab, bahasa melayu tersebutlah yang mereka kuasai dan satusatunya bahasa yang bisa mereka gunakan untuk berinteraksi dengan mahasiswa lainnya, sedangkan ketika berkomunikasi antar teman dari Thailand, mereka menggunakan bahasa Thailand. Kondisi ini membuat mereka menjadi sulit bertukar informasi dengan mahasiswa lainnya.

Kemampuan memahami dan terampil berbicara bahasa Indonesia merupakan hal yang terpenting bagi para mahasiswa UM Palangkaraya dari Thailand, sebab : 1). Kemampuan memahami dan terampil berbicara bahasa Indonesia merupakan modal utama untuk mampu bersosialisasi dengan masyarakat di Indonesia, khususnya masyarakat yang berada di
Palangka Raya. Khususnya lagi, berkomunikasi dengan para dosen dan teman-teman di Universitas Muhammadiyah Palangkaraya, dan 2). Pilihan konsentrasi ilmu yang diambil oleh mahasiswa dari Thailand adalah konsentrasi pada ilmu pendidikan, dimana mereka disiapkan untuk menjadi seorang guru, sedangkan modal utama mereka dalam berbahasa Indonesia masih kurang sehingga dapat mempengaruhi proses pembelajaran ketika nantinya mereka diminta melakukan praktik lapangan. Oleh karena itu, perlu kiranya dilakukan pembelajaran keterampilan berbicara yang lebih dalam lagi guna melatih keterampilan berbicara mahasiswa dan mahasiswi dari Thailand ini menggunakan bahasa Indonesia yang lebih fasih.

Bagi mahasiswa angkatan 2014-2015, mereka sudah memiliki dasar-dasar berbicara bahasa Indonesia. Mereka mengungkapkan pada mahasiswa angkatan 2015-2016, bahwa pada awalnya mereka juga mengalami kesulitan yang sama untuk berkomunikasi dengan mahasiswa lainnya. Tetapi, mereka tetap berusaha menyesuaikan diri dan bahasanya dengan mahasiswa lain sehingga sedikit demi sedikit akhirnya mereka mampu menggunakan bahasa Indonesia meskipun tidak terlalu fasih. Walaupun demikian, hal ini tidaklah cukup, sebab interaksi dan komunikasi yang mereka lakukan tidak hanya sesama teman-temannya saja. Melainkan interaksi dan berkomunikasi dengan dosen dan masyarakat sekitarnya. Hal ini tidak hanya menjadi kendala bagi mahasiswa dari Thailand tetapi juga menjadi kendala bagi pengajarnya/dosen, dan masyarakat sekitarnya ketika berinteraksi dengan mereka karena tidak semua dosen dan masyarakat mampu 
menggunakan bahasa melayu. Hal ini juga mempersulit berbagai pihak pendengar untuk memahami pembicaraan yang mereka bicarakan dengan bahasa melayu karena kemampuan mereka berbicara dalam bahasa melayu itu sendiri masih kurang atau tidak terlalu fasih.

Untuk membantu kelancaran dalam berkomunikasi dengan mahasiswa dari Thailand juga dibantu oleh berbagai pihak, yaitu dengan melibatkan dosen-dosen yang turut membantu mahasiswa dari Thailand ini secara perlahan dalam mempelajari bahasa Indonesia. Dalam melakukan pembelajaran, pengajar berusaha menjelaskan materi ajar menggunakan bahasa yang mudah untuk mereka pahami. Seperti halnya ketika ada kata-kata yang tidak dapat dipahami, akan diganti dengan kata lain yang memiliki makna yang sama agar lebih mudah mengerti dan memahaminya. Bila tidak mengerti juga, dosen menerjemahkan kata tersebut ke dalam bahasa Inggris dan meminta mahasiswa tersebut menerjemahkannya ke dalam bahasa Thailand. Dengan begitu, dapat membantu mahasiswa untuk memahami hal yang dimaksud.

Bagi mahasiswa angkatan 2015/2016, kendala terbesar adalah ketidakmampuan berkomunikasi dalam bahasa Indonesia meskipun hanya bagian dasarnya, seperti:

1. Sulitnya melafalkan kosakata yang sederhana dalam bahasa Indonesia;

2. Sulitnya menyampaikan keinginan dan pendapat dengan teman-teman di Universitas Muhammadiyah Palangkaraya;

3. Sulitnya menyampaikan keinginan dan pendapat kepada dosen-dosen dan masyarakat;

4. Sulitnya memahami materi kuliah dari dosen;
5. Sulitnya mengerjakan tugas dari dosen, baik menguraikan dalam bentuk lisan maupun tulisan ke dalam bahasa Indonesia.

Setiap negara memiliki bahasa nasional masing-masing. Negara Indonesia, bahasa nasionalnya adalah bahasa Indonesia. Bahasa Indonesia ini wajib dikuasai oleh seluruh warga negara Indonesia secara khusus dan warga negara asing secara umum. Sesuai dengan penggunaan sehari-hari di dalam bahasa Indonesia terbagi atas dua jenis bahasa, yaitu bahasa Indonesia baku dan bahasa Indonesia tidak baku. Semestinya, warga Indonesia memahami keduanya. Selain itu, di dalam bahasa Indonesia terdapat keanekaragaman kata yang memiliki kesamaan arti atau makna yang tidak semuanya mampu dipahami oleh warga negara Indonesia, apalagi oleh warga negara asing.

Persoalan utama yang dihadapi apabila warga negara Indonesia bertemu warga negara asing adalah persoalan bahasa. Tidak semua warga negara Indonesia memahami bahasa warga negara asing tersebut. Demikian juga sebaliknya, tidak semua warga negara asing mampu memahami bahasa Indonesia.

Pertukaran pelajar atau mahasiswa adalah suatu hal yang sudah dilakukan oleh berbagai negara, termasuk Indonesia, khususnya di Universitas Muhammadiyah Palangkaraya. Universitas Muhammadiyah Palangkaraya beberapa tahun ini telah mencoba bekerja sama dengan beberapa negara dalam rangka peningkatan kompetensi dosen dan mahasiswa. Salah satunya bekerja sama dengan negara Thailand sebagai wadah pengembangan mahasiswa. Pihak Universitas Muhammadiyah Palangkaraya mengirimkan mahasiswa yang 
mengikuti Kuliah Kerja Nyata (KKN) untuk belajar berbagai macam hal di negara Thailand, khususnya Thailand Selatan, sedangkan pihak Thailand Selatan mengirimkan mahasiswa yang baru lulus Sekolah Menengah Atas (SMA) untuk menempuh pendidikan di Universitas Muhammadiyah Palangkaraya sebagai mahasiswa baru sampai dengan selesai menjadi sarjana. Adapun program studi yang dipilih mahasiswa tersebut adalah Program Studi Pendidikan Ekonomi, Pendidikan Guru Sekolah Dasar dan Pendidikan Agama Islam.

Berdasarkan kemampuan berbahasa, baik mahasiswa Universitas Muhammadiyah Palangkaraya yang dikirimkan ke Thailand Selatan maupun mahasiswa Thailand yang menempuh pendidikan strata satu di Universitas Muhammadiyah Palangkaraya sama-sama tidak memiliki kemampuan untuk berbahasa nasional masing-masing negara. Bahasa yang digunakan untuk berkomunikasi adalah bahasa melayu. Itu pun dengan kemampuan yang tidak benar-benar menguasai bahasa melayu secara penuh. Seperti yang sudah diketahui bahwa keterampilan berbicara merupakan kemampuan mengucapkan bunyi-bunyi artikulasi atau kata-kata untuk mengekspresikan, mengatakan serta menyampaikan pikiran, gagasan dan perasaan. Pendengar menerima informasi melalui rangkaian nada, tekanan, dan penempatan persendian. Jika komunikasi berlangsung secara tatap muka ditambah lagi dengan gerak tangan dan air muka (mimik) pembicara. Selain itu, keterampilan berbicara juga dikatakan sebagai keterampilan menyampaikan pesan melalui bahasa lisan. Kaitan antara pesan dan bahasa lisan sebagai media penyampaian sangat erat. Pesan yang diterima oleh pendengar tidaklah dalam wujud asli, tetapi dalam bentuk lain, yakni bunyi bahasa. Pendengar kemudian mencoba mengalihkan pesan dalam bentuk bunyi bahasa itu menjadi bentuk semula. Oleh karena itu, perlu diadakan pembelajaran atau pelatihan keterampilan berbicara bahasa Indonesia kepada mahasiswa dari Tailand yang ada di Universitas Muhammadiyah Palangkaraya karena dalam menempuh pendidikan di wilayah Indonesia diharapkan memiliki bekal atau dasar-dasar dalam berbahasa Indonesia untuk mengerti dan memahami maksud dari pesan yang disampaikan.

\section{Permasalahan}

Berdasarkan hasil pengamatan dan wawancara dengan mahasiswa Thailand angkatan 2015/2016 bahwa yang menjadi masalah mendasar ialah:

1. Ketidakmampuan mereka untuk menangkap atau memahami pembicaraan dosen yang berbicara dengan cepat karena mereka hanya bisa memahami sebuah pembicaraan dengan perlahan itupun harus menggunakan bahasa melayu!

2. Sulitnya untuk berkomunikasi dan memahami materi pelajaran sehingga mereka harus mencatat materi yang dijelaskan dosen dari awal sampai akhir, kemudian meminta bantuan kepada kakak tingkat untuk menterjemahkannya.

\section{Tujuan}

Pembelajaran keterampilan berbicara ini bertujuan untuk: 1). melatih mahasiswa dari Thailand agar dapat berkomunikasi dalam bahasa Indonesia, 2). melatih mahasiswa dari Thailand agar mampu menangkap atau memahami pembicaraan dosen yang berbicara dengan cepat, 
dan 3). melatih mahasiswa dari Thailand agar mampu berkomunikasi dan memahami materi pelajaran sehingga mereka tidak perlu mencatat materi yang dijelaskan dosen dari awal sampai akhir dan tidak perlu meminta bantuan kepada temannya maupun kepada kakak tingkat untuk menterjemahkannya.

\section{METODE PELAKSANAAN}

\section{Waktu dan Tempat}

Pelaksanaan kegiatan pengabdian kepada masyarakat dilaksanakan selama 2 (dua) bulan dengan pertemuan sebanyak 24 (dua puluh empat) kali pertemuan yang dilaksanakan setiap minggu sebanyak 3 (tiga) kali pertemuan. Kegiatan pengabdian kepada masyarakat ini dilaksanakan menggunakan anggaran pendanaan pada tahun 2015. Lokasi kegiatan pelatihan keterampilan bahasa Indonesia pada mahasiswa dari Thailand dilaksanakan dan dipusatkan di lingkungan Universitas Muhammadiyah Palangkaraya yang menggunakan ruang kelas $A$ 26 dan di laboratorium bahasa UPT Laboratorium Terpadu UM Palangkaraya.

\section{Sasaran Kegiatan}

Masyarakat sasaran yang menjadi subyek pengabdian kepada masyarakat adalah mahasiswa-mahasiswa yang kuliah di Universitas Muhammadiyah Palangkaraya yang berasal dari Thailand yang berjumlah 8 (delapan) orang. Terdiri dari 3 (tiga) orang laki-laki dan 5 (lima) orang perempuan. Kedelapan mahasiswa ini ialah mahasiswa yang terdiri dari 5 (lima) orang mahasiswa semester tiga dan 3 (tiga) orang mahasiswa semester 1 (satu). Adapun pelaksana (pelatih) kegiatan pengabdian kepada masyarakat ini berjumlah 3 (tiga) orang dengan bidang ilmu Pendidikan Bahasa dan Sastra Indonesia dan bidang ilmu Psikologi Pendidikan.

\section{Metode Kegiatan}

Metode yang digunakan dalam kegiatan belajar mengajar keterampilan berbicara menggunakan dua metode, yaitu: (a)Metode linguistik ialah menggunakan pendekatan ilmiah karena yang menjadi landasan pembelajaran adalah hasil dari penelitian para linguis (ahli bahasa). Urutan penyajian bahan pembelajaran disusun sesuai tahap-tahap kesukaran yang mungkin dialami siswa. Dengan demikian pada metode ini tidak dilarang menggunakan bahasa ibu murid, karena bahasa ibu murid akan memperkuat pemahaman bahasa tersebut; dan (b) Metode bibahasa ialah metode yamg hampir sama dengan metode linguistik, bahasa ibu murid digunakan untuk menerangkan perbedaanperbedaan fonetik, kosakata, struktur kalimat, dan tata bahasa kedua bahasa itu.

\section{Solusi yang Ditawarkan}

Berdasarkan masalah yang dihadapi mahasiswa tersebut maka terdapat enam solusi yang ditawarkan dalam pelatihan ini sesuai dengan kebutuhannya, yaitu keterampilan berbicara bahasa Indonesia pada tingkat pemula. Keenam solusi tersebut akan diuraikan di bawah ini.

1. Belajar mengeja alfabet dan angka sesuai dengan ejaan yang disempurnakan dalam tata bahasa baku.

2. Belajar menyusun kalimat perkenalan, berlatih mengenalkan diri dalam bahasa Indonesia, mengenal kalimat sapaan dan berlatih membuat contoh kalimat sapaan beserta melafalkannya. 
3. Mengenal dan berlatih mengucapkan kata ganti : orang, penunjuk, penanya.

4. Mengenal dan berlatih mengucapkan kata tanya, kalimat tanya, kalimat berita.

5. Mengenal dan berlatih mengucapkan kalimat perintah, kalimat mengeritik, kalimat meminta maaf dalam bentuk bahasa Indonesia.

6. Mengajak mahasiswa untuk berdialog singkat dengan mahasiswa lain yang dilakukan di luar kelas untuk melihat batas kemampuan mahasiswa dalam berinteraksi menggunakan bahasa Indonesia.

\section{HASIL DAN PEMBAHASAN}

Secara keseluruhan, kegiatan berjalan lancar sesuai rencana. Peserta dapat mengikuti materi-materi pelatihan dengan baik. Demikian juga dengan tugas yang diberikan, dapat dikerjakan sesuai dengan yang diharapkan. Berkenaan dengan evaluasi kegiatan, banyak hal yang menjadi evaluasi. Dari hasil evaluasi dampat disimpulkan bahwa peserta sudah memiliki kemampuan dalam berbicara bahasa Indonesia. Selain itu, peserta juga cukup paham cara pelafalan bahasa Indonesia yang baik dan benar meskipun ada bagian-bagian pengucapkan yang terpengaruh oleh dialek mereka sehingga perlu dilatih dan diasah lagi. Namun, hal tersebut bukanlah menjadi masalah besar karena semuanya akan bisa diatasi dengan selalu diasah. Selain itu, peserta juga dapat menangkap pembelajaran dengan cepat sehingga mereka mudah mengerti mengenai materi yang disampaikan. Peserta sudah dapat membuat beberapa kalimat yang berhubungan dengan materi. Sedangkan untuk membuat beberapa kalimat dalam satu paragraf atau lebih, peserta masih memadukan antara bahasa Indonesia dengan bahasa Melayu. Hal ini tampak tidak hanya secara lisan tetapi juga melalui tulisan.

Pada pertemuan pertama, materi pelatihan yang diberikan adalah pelafalan alfabet. Peserta dibimbing untuk melafalkan huruf $A$ sampai huruf Z. Awal pelafalan, peserta masih menggunakan logat bahasa Melayu dan terpengaruh oleh pelafalan bahasa Inggris. Sebab, pelafalan alfabet di negara Thailand Selatan menggunakan pelafalan bahasa Inggris. Perbedaan pelafalan tersebut, dapat dilihat pada tabel 3 dibawah ini :

Tabel 1. Perbedaan pelafalan Bahasa Indonesia dengan Bahasa Melayu Mahasiswa Thaliland di UM Palangkaraya

\begin{tabular}{cccc}
\hline No. & Huruf & $\begin{array}{c}\text { Pelafalan } \\
\text { Bahasa } \\
\text { Indonesia }\end{array}$ & $\begin{array}{c}\text { Pelafalan } \\
\text { Bahasa Melayu/ } \\
\text { Bahasa Inggris }\end{array}$ \\
\hline 1. & $\mathrm{A}$ & $\mathrm{A}$ & $\mathrm{Ei}$ \\
2. & $\mathrm{B}$ & $\mathrm{Be}$ & $\mathrm{Bi}$ \\
3. & $\mathrm{C}$ & $\mathrm{Ce}$ & $\mathrm{Si}$ \\
4. & $\mathrm{D}$ & $\mathrm{De}$ & $\mathrm{Di}$ \\
5. & $\mathrm{E}$ & $\mathrm{E}$ & $\mathrm{I}$ \\
6. & $\mathrm{F}$ & $\mathrm{Ef}$ & $\mathrm{Ef}$ \\
7. & $\mathrm{G}$ & $\mathrm{Ge}$ & $\mathrm{Ji}$ \\
8. & $\mathrm{H}$ & $\mathrm{Ha}$ & $\mathrm{Eitc}$ \\
9. & $\mathrm{I}$ & $\mathrm{I}$ & $\mathrm{Ai}$ \\
10. & $\mathrm{J}$ & $\mathrm{Je}$ & $\mathrm{Jei}$ \\
11. & $\mathrm{K}$ & $\mathrm{Ka}$ & $\mathrm{Kei}$ \\
12. & $\mathrm{L}$ & $\mathrm{El}$ & $\mathrm{El}$ \\
13. & $\mathrm{M}$ & $\mathrm{Em}$ & $\mathrm{Em}$ \\
14. & $\mathrm{N}$ & $\mathrm{En}$ & $\mathrm{En}$ \\
15. & $\mathrm{O}$ & $\mathrm{O}$ & $\mathrm{Ou}$ \\
16. & $\mathrm{P}$ & $\mathrm{Pe}$ & $\mathrm{Pi}$ \\
17. & $\mathrm{Q}$ & $\mathrm{Ki}$ & $\mathrm{Kyu}$ \\
18. & $\mathrm{R}$ & $\mathrm{Er}$ & $\mathrm{Ar}$ \\
19. & $\mathrm{S}$ & $\mathrm{Es}$ & $\mathrm{Es}$ \\
20. & $\mathrm{T}$ & $\mathrm{Te}$ & $\mathrm{Ti}$ \\
21. & $\mathrm{U}$ & $\mathrm{U}$ & $\mathrm{Yu}$ \\
22. & $\mathrm{V}$ & $\mathrm{Fe}$ & $\mathrm{Vi}$ \\
23. & $\mathrm{W}$ & $\mathrm{We}$ & $\mathrm{Dablyu}$ \\
24. & $\mathrm{X}$ & $\mathrm{Eks}$ & $\mathrm{Eks}$ \\
25. & $\mathrm{Y}$ & $\mathrm{Ye}$ & $\mathrm{Wai}$ \\
26. & $\mathrm{Z}$ & $\mathrm{Zet}$ & $\mathrm{Zed}$ \\
\hline & & & \\
\hline
\end{tabular}




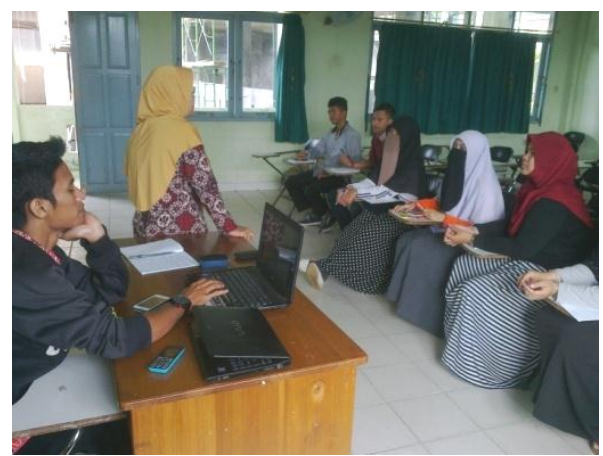

Gambar 1. Pembukaan pertemuan pelatihan

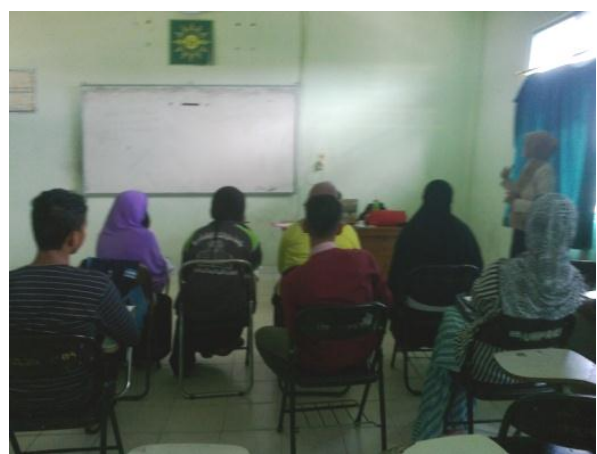

Gambar 3. Menjelaskan pengucapan angka

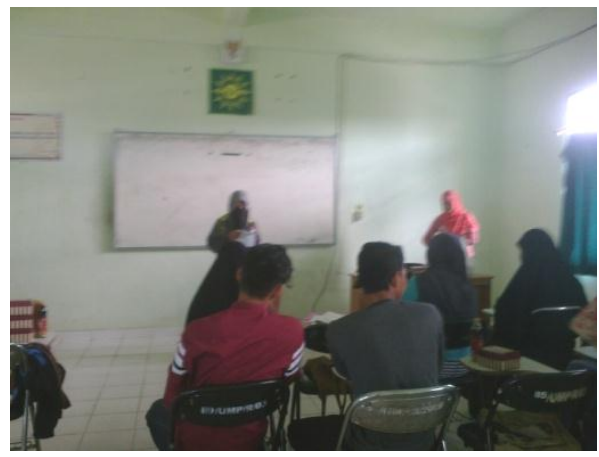

Gambar 5. Menguraikan kalimat perkenalan

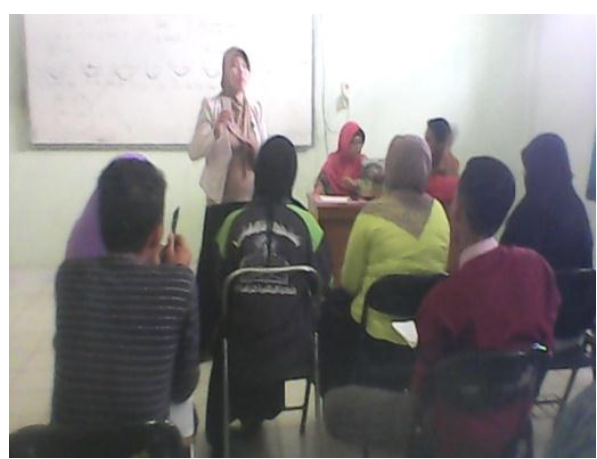

Gambar 7. Mengucapkan dialog kalimat sapaan

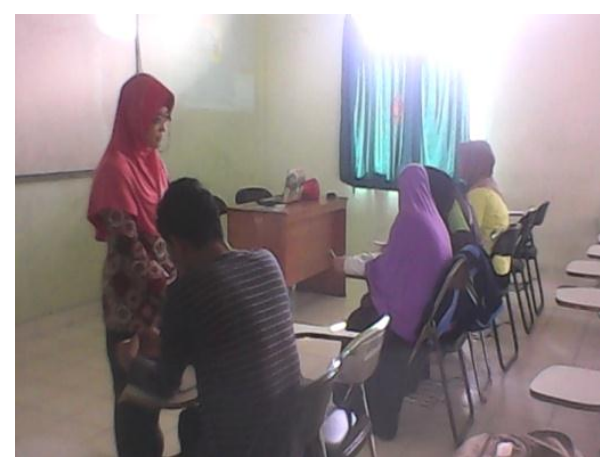

Gambar 2. Menyampaikan materi/bahan ajar

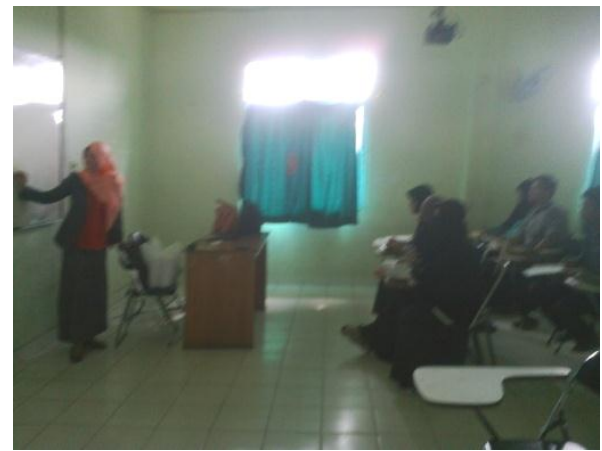

Gambar 4. Menjelaskan kalimat sederhana

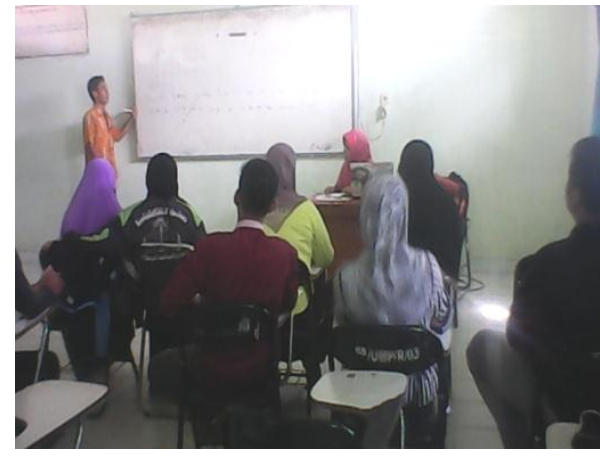

Gambar 6. Pengucapan perkenalan diri

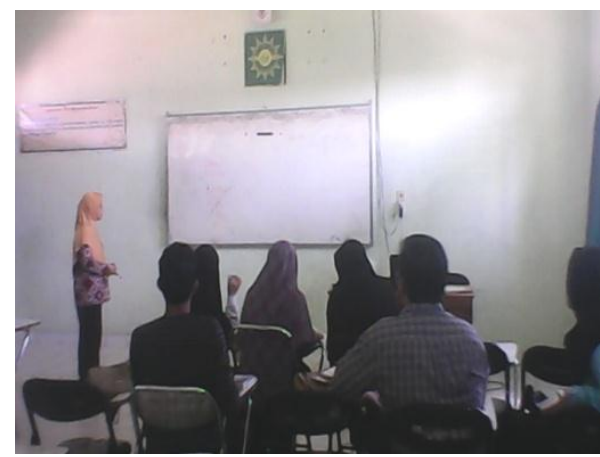

Gambar 8. Kata ganti dalam berbicara 
Setelah dibimbing, peserta dapat melafalkan alfabet sesuai dengan lafal ejaan Bahasa Indonesia atau ejaan yang disempurnakan. Walaupun demikian, ada beberapa pelafalan yang masih sulit untuk diucapkan seperti huruf $F, L, M, N, Q, R, W$. Selain itu, peserta juga mengalami kesulitan di dalam melafalkan huruf $P$ dan V. Sebab, kedua huruf ini memiliki kemiripan di dalam sisi pendengaran sehingga cara melafalkannya sama.

Saat berkomunikasi, para peserta mengalami kesulitan di dalam pelafalan kosa kata yang tampak pada penggunaan huruf vokal: a, dan o, serta melafalkan huruf konsonan: $r, k$, t. Kesulitan pengucapan huruf "a" umumnya dialami pada kata-kata yang di dalam kata tersebut terdapat dua huruf yang terletak di awal kata dan di akhir kata. Huruf "a" diawal kata dapat dilafalkan dengan baik sesuai ejaan bahasa Indonesia. Tetapi, ketika masuk pada pengucapan huruf "a" yang terletak di akhir kata dilafalkan menjadi pelafalan huruf "e" atau terdengar "ae" seperti penggunaan kata "apa menjadi apae". Contoh lain dengan pelafalan "a" menjadi "e" atau "ae" ialah penggunaan kat "saja menjadi sajae", "nama menjadi namae", "saya menjadi sayae". Contoh pelafalan huruf "a" menjadi "o" adalah saat menyebutkan kata "tiga menjadi/terdengar tigo". Sedangkan pelafalan huruf "o" dilafalkan menjadi huruf "u". Misalnya pada kata: "semoga menjadi semuga" dan "halo menjadi halu".

Kesulitan pelafalan huruf konsonan "k dan t" yang terletak di akhir kata menjadi luluh atau dihilangkan seolah-olah terdengar ada tanda (') seperti, melafalkan kata: "baik-baik menjadi ba'iba'ï", "anak menjadi ana"”, "sepak menjadi sepa"”, dan "empat menjadi empa"'. Untuk pelafalan huruf "r" dilafalkan "ar" atau terdengar seperti pelafalan huruf "l" seperti pelafalan dalam bahasa Inggris. Contohnya, "pagar mengjadi pagaar atau terdengar pagal". Hal ini disebabkan di negara Thailand, khususnya Thailand Selatan hanya sedikit kata-kata yang menggunakan huruf "r".

Selain kesulitan melafalkan huruf konsonan yang terletak di akhir kata. Peserta juga mengalami kesulitan membuat kalimat dengan menggunakan kata ganti. Kesulitan terletak pada penggunaan kata ganti yang jarang mereka dengar, seperti: hamba, dikau, dan beliau. Peserta mengalami kebingungan saat diminta untuk membuat kalimat pendek. Awalnya semua peserta kesulitan untuk membuat kalimat yang memuat kata "hamba, dikau, dan beliau". Namun, dengan seringnya dilatih dan dijelaskankan makna dari kata tersebut hingga beberapa mahasiswa cukup mampu membuat kalimat dengan kata ganti tersebut. Tetapi, masih ada juga beberapa peserta yang terdiri dari 2-3 orang saja yang belum bisa membuat kalimat menggunaka kata ganti "hamba, dikau, dan beliau".

Pengaruh lain yang menyebabkan keterampilan berbicara bahasa Indonesia peserta masih rendah karena adanya pengaruh bahasa melayu yang masih kental. Pengaruh bahasa melayu ini tampak kental pada dialek seluruh peserta sehingga ketika mereka merangkaikan kosa kata menjadi kalimat pelafalan terdengar kurang jelas. Namun, pada pelafalan kata per kata peserta dapat dikatakan bahwa peserta sudah cukup mampu mengucapkannya dan penggunaan katanya dapat didengar dengan jelas meskipun ada sedikit dialek melayunya. 


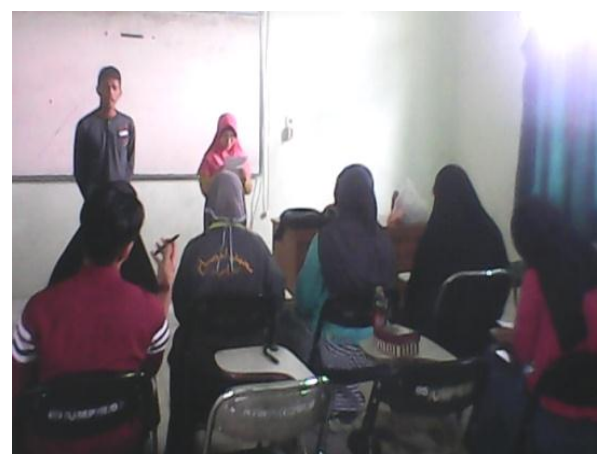

Gambar 9. Membuat kalimat tanya

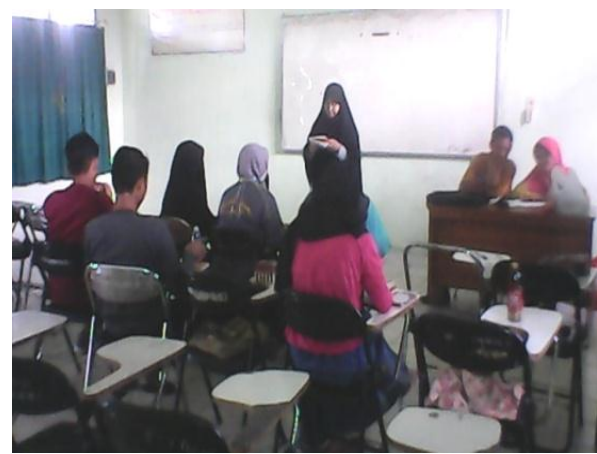

Gambar 11. Membuat kata sapaan dan kata ganti

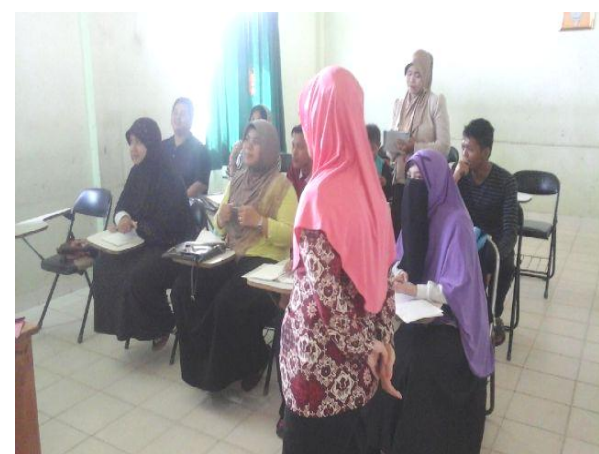

Gambar 13. Menyusun kalimat meminta maaf

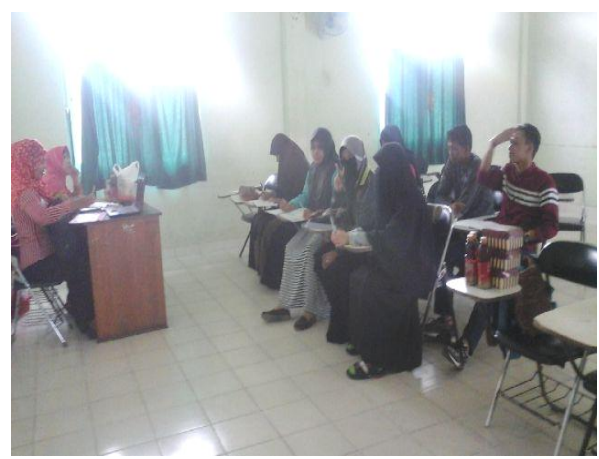

Gambar 15. Kalimat mengeritik dalam berbicara

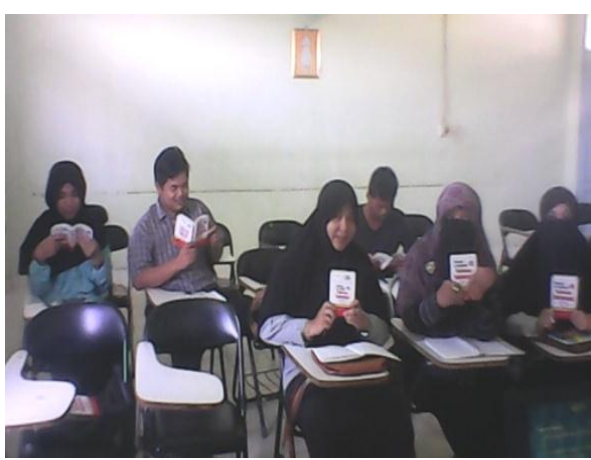

Gambar 10. Mencari kata ganti dalam kamus BI

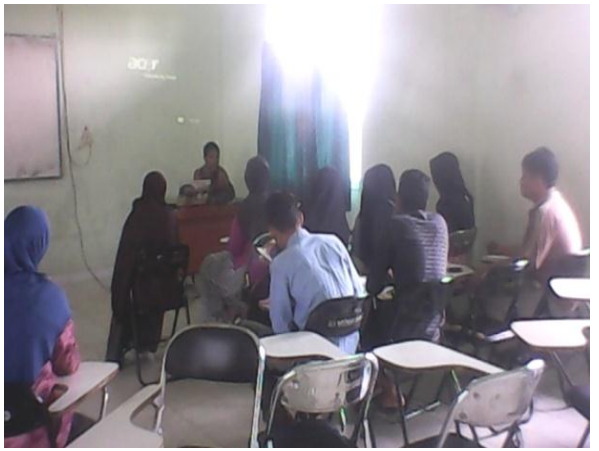

Gambar 12. Menjelaskan kalimat berita

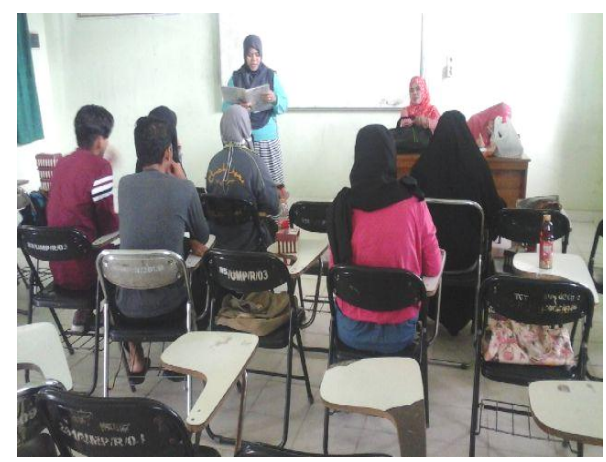

Gambar 14. Berbicara BI memperhatikan EYD

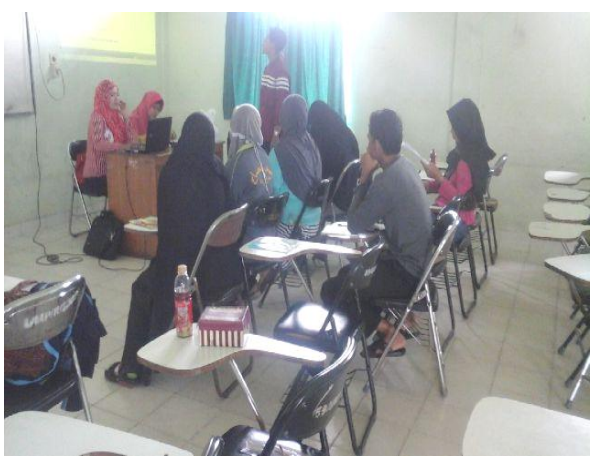

Gambar 16. Melakukan kritik yang sopan 
Masyarakat sasaran dalam hal ini adalah mahasiswa asal Thailand yang menempuh perkuliahan di UM Palangkaraya nampaknya memiliki kontribusi yang cukup baik di dalam kegiatan pelatihan keterampilan berbicara bahasa Indonesia. Seluruh peserta aktif di dalam mengikuti kegiatan pelatihan, baik itu sesuai rancangan dari tim pengabdian kepada masyarakat maupun yang terjadi secara alami. Beberapa diantara peserta ada yang sering bertanya dan ada juga yang perlu diberi stimulus seperti pertanyaan. Kemudian meresponnya.

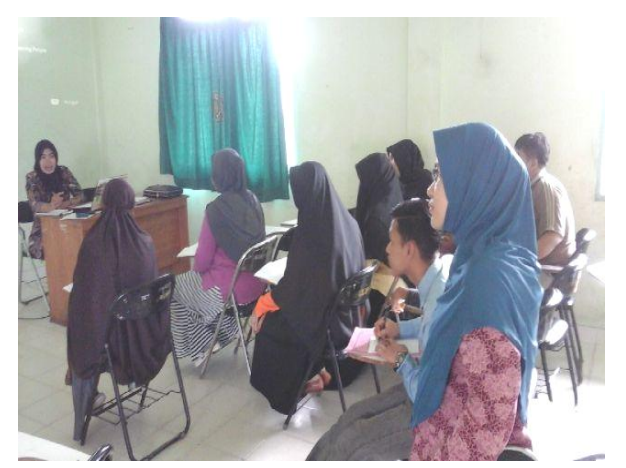

Gambar 17. Praktek berbicara meminta maaf

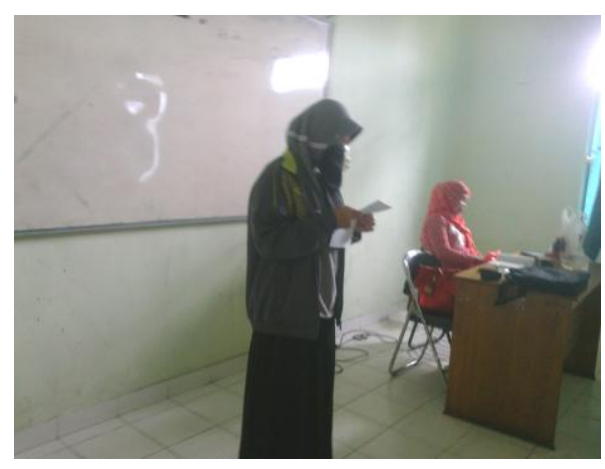

Gambar 19. Praktek dialog melalui tulisan
Setiap peserta mahasiswa asal Thailand yang menempuh perkuliahan di UM Palangkaraya nampaknya bertanggung jawab terhadap tugastugas yang diberikan. Mereka berusaha dengan kemampuan yang dimiliki untuk mengikuti materi pelatihan dan mempraktekkannya melalui tulisantulisan dan membuat kalimat-kalimat sederhana. Seluruh peserta datang tepat waktu dan pulang sesuai dengan waktu yang ditentukan. Selain itu, semua peserta juga disiplin ketika proses belajar mengajar berlangsung sehingga mempercepat proses keterampilan berbahasa Indonesia.

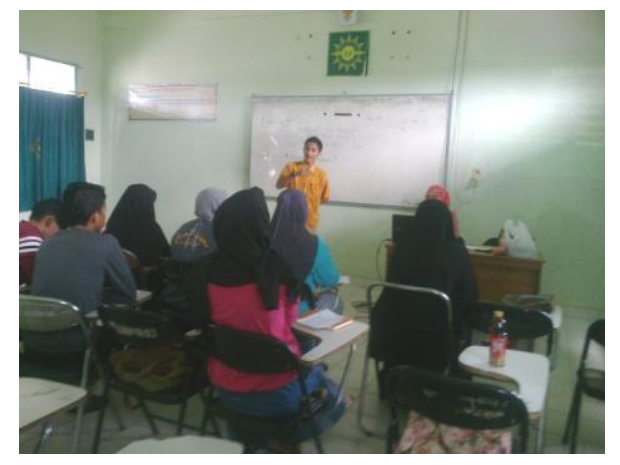

Gambar 18. Praktek berbicara kalimat pendek

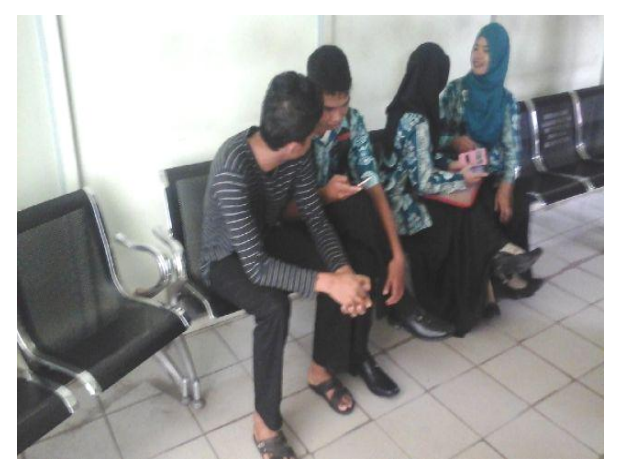

Gambar 20. Praktek dialog pendek berteman 


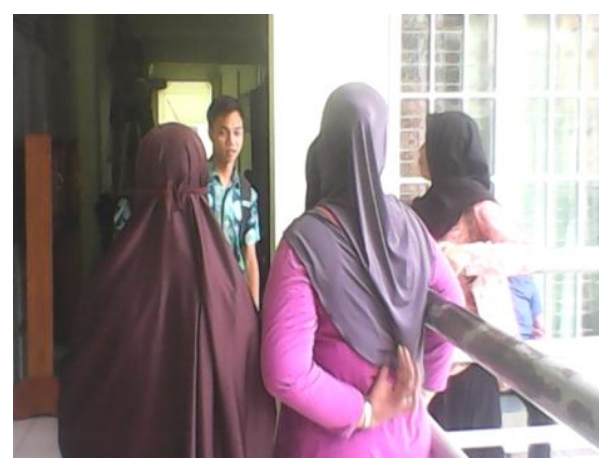

Gambar 21. Melakukan praktek dialog bertanya

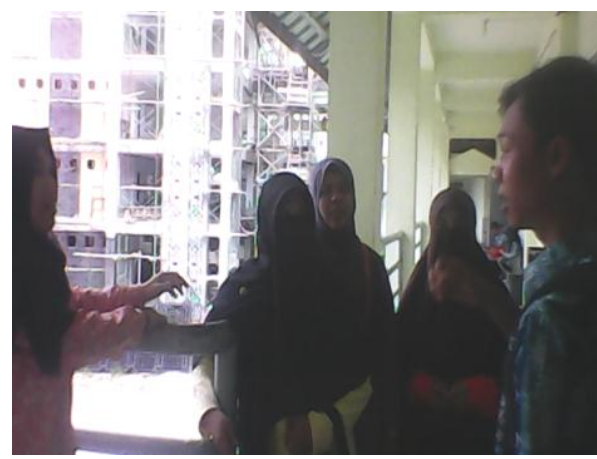

Gambar 23. Praktek dialog diskusi

\section{SIMPULAN DAN SARAN}

\section{Simpulan}

Keterampilan berbicara merupakan salah satu cabang dari ilmu keterampilan berbahasa. Dalam pembelajaran keterampilan berbicara pada tahap pemula diperlukan pelatihan yang khusus karena belajar bahasa Indonesia pada tahap pemula hampir sama seperti halnya dengan belajar bahasa asing. Bagi masyarakat sekitarnya bahasa Indonesia merupakan alat untuk berkomunikasi dan bertukar informasi. Selain itu, juga sebagai alat penghubung antar suku yang menggunakan bahasa yang berbeda. Bagi masyarakat luar wilayah seperti halnya mahasiswa dari Thailand menganggap bahwa

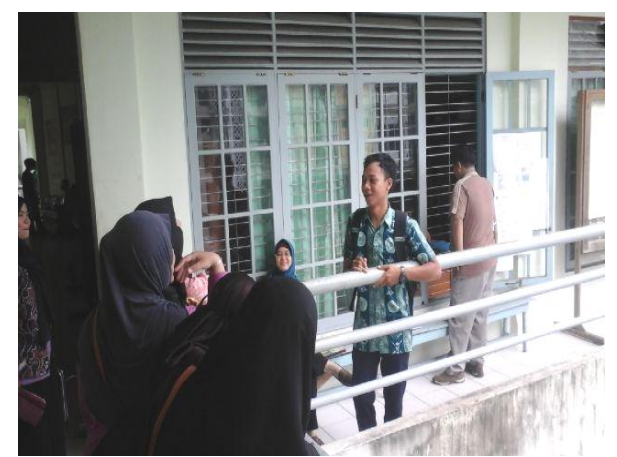

Gambar 22. Praktek dialog menyapa teman

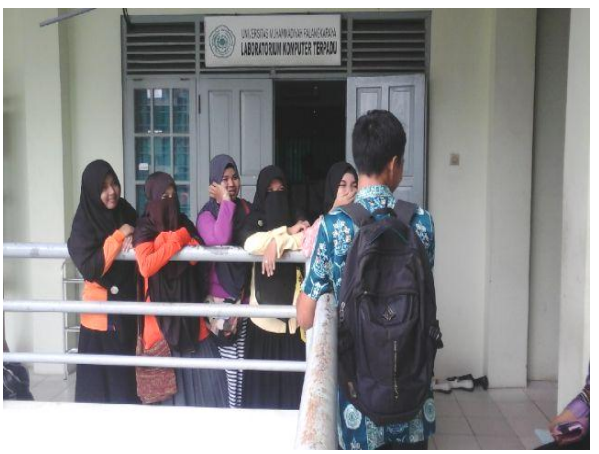

Gambar 24. Praktek dialog diskusi

belajar bahasa Indonesia sama halnya dengan mempelajari bahasa asing karena belajar bahasa yang baik dan benar perlu dibimbing secara khusus agar dapat membedakan yang mana bahasa yang baik untuk digunakan atau yang tidak baik. Oleh karena itu, belajar keterampilan berbahasa diperlukan juga pedoman-pedoman khusus seperti kamus bahasa Indonesia dan pedoman EYD.

Kemampuan berbahasa Indonesia mahasiswa dari Thailand kebanyaknya terpengaruh oleh bahasa Melayu sehingga diperlukan pembelajaran berbicara dari tahap awal. Berdasarkan hasil pelatihan dapat dikatakan bahwa mahasiswa dari Thailand cukup mampu dan lumayan cepat mempelajari bahasa 
Indonesia dengan baik meskipun tidak semua mahasiswa yang berasal dari Thailand yang dapat menggunakan bahasa Indonesia dengan baik dan benar. Namun, dengan diadakan pelatihan keterampilan berbicara bahasa Indonesia setidaknya mahasiswa dari Thailand dapat mengetahui dasar-dasar berbahasa Indonesia, seperti halnya dapat membedakan cara pengucapan vokal dan konsonan bahasa Indonesia dengan bahasa Melayu/asing dan juga dapat membuat kalimat-kalimat pendek dalam bahasa Indonesia dengan memperhatikan pedoman bahasa yang baik dan benar.

\section{Saran}

Pelatihan keterampilan berbicara ini perlu kiranya dilanjutkan agar mahasiswa dari Thailand tersebut tidak hanya bisa berbahasa Indonesia secara pasif tetapi juga sacara aktif. Selain itu, juga diharapkan agar mahasiwa mampu merangkai sebuah kalimat yang lebih panjang lagi atau ke dalam bentuk paragraf.

\section{UCAPAN TERIMA KASIH}

Ucapan terima kasih disampaikan kepada Universitas Muhammadiyah Palangkaraya yang telah memfasilitasi dan membantu pendanaan pembiayaan kegiatan pengabdian kepada masyarakat pada Tahun Anggaran 2015 ini. Terimakasih juga disampaikan kepada semua pihak yang mendukung dan memfasilitasi kegiatan ini, khususnya kepada para mahasiswa asal Thailand di UM Palangkaraya yang secara aktif berpartisipasi dan penuh semangat selama pelatihan ini.

\section{DAFTAR PUSTAKA}

Menteri Pendidikan dan Kebudayaan Republik Indonesia. 2011. EYD Pedoman Umum Ejaan Bahasa Indonesia yang Disempurnakan. Victori Inti Cipta.

Pusat Bahasa Departemen Pendidikan Nasional. 2008. Kamus Bahasa Indonesia. Edisi Ketiga. Jakarta: Balai Pustaka.

Suharyanti. 2011. Pengantar Keterampilan Berbicara. Surakarta: Yuma Pustaka. 